\title{
Reinforcement of Hybrid Fibre Reinforced Concrete Beam using Steel and Polypropylene Fibre
}

\author{
M.Hemapriya, T.P.Meikandaan, A. Arokia Prakash
}

\begin{abstract}
Most commonly the reinforced concrete structures fail by exhibiting the flexural and shear pattern of cracks. So in order to avoid this type of failure and to increase the life span of the structure, the strengthening of the structural members has to be studied. The concept of using fibres in the concrete has more advantage in increasing the concrete strength. However, in this investigation two different types of fibre which has higher (Steel hooked end fibre) and lesser moduli (Polypropelene fibre) which increases the modulus of elasticity of concrete. This Hybrid combination of fibres will reduce the chances of brittleness and small crack formation in the concrete. The use of computer software to model these elements is much faster, and extremely cost-effective. Hence, the Non-linear Finite Element Analysis (FEA) of a Hybrid fibre reinforced concrete beams has been modelled and analysed using the ANSYS software package. The flexure and shear pattern of arrangements in control beam and three Hybrid fibre Reinforced concrete beams of different proportions (1\%, $1.5 \%$ and $2 \%$ ) were modeled and analyzed for the results of ultimate load, deflection and stiffness ratio of the beams.
\end{abstract}

Keywords - Hybrid fibre reinforced concrete, steel hooked fibre, polypropylene fibre, ANSYS, FEA

\section{INTRODUCTION}

Fibre reinforced concrete is a composite material that is made of concrete and short fibres. The fibres can be considered as, more or less, uniformly distributed and their orientation is usually random. Fibre-reinforced concrete can also be combined with conventional reinforcement (steel bars) and post-tensioning or prestressing. Although fibre-reinforced concrete is a relatively young material, some cultures have used fibres as reinforcement in other materials in different ways. For example, old buildings were made of clay and straw fibres, and the builders made them without any significant technical knowledge[1]-[4].

Apart from the issue of the cost, there are many advantages in the use of FRC:

- Improved post-peak response in flexural, which means increased capacity to carry load. The post-peak response usually begins when elastic limit of the concrete in tension is reached

Revised Manuscript Received on October 22, 2019.

M.Hemapriya, Department of Civil Engineering, Bharath Institute of Higher Education and Research, Chennai , India. Email: meihemapriya@gmail.com

T.P.Meikandaan, Department of Civil Engineering, Bharath Institute of Higher Education and Research, Chennai , India. Email: ganga_meik@yahoo.co.in of Higher Education and Research, Chennai, India. Email: prakash.arokiasamy@gmail.com
A. Arokia Prakash, Department of Civil Engineering, Bharath Institute

- Improved tensile ductility.

- Possible to achieve a 3-D distribution of the fibres, which is favourable for triaxial loads.

- Excellent repair material, e.g. old structures

- Probably reduced cost of the execution of the work, moreover, the work techniques of manufacturing and distribute fibres are developing quite fast.

- Advantages in durability

There is, nevertheless, not so much information about the structural behaviour of the FRC structures and if it is possible that the conventional reinforcement can be avoided completely. Hence, there is a long path to travel until FRC is a commonly used material[5]-[8].

\section{A. Application of FRC}

Most of the actual applications of FRC are in non-structural or semi structural elements. This is mostly due to the fact that there is no completely developed code available or a systematic guide to design elements made of FRC. Examples of applications are: pavements, walls, beams, slabs, tunnel-linings, etc. The use of FRC in these applications also leads to improvements in their behaviour.

These depend on the type of load:

- Flexural members - Improves the post-peak response and increase the post-peak load.

- Shear loads - Increased shear capacity and post-cracking safety[9]-[13].

- Torsion loads - Increased torsional capacity and post-cracking safety.

- Uniaxial tension- members increased joint spacing and reduced crack widths.

New application areas may be discovered as more tests and investigations are conducted. For that reason, it is important to define a good and not too complicated code that is useful for all the designers who want to use FRC.

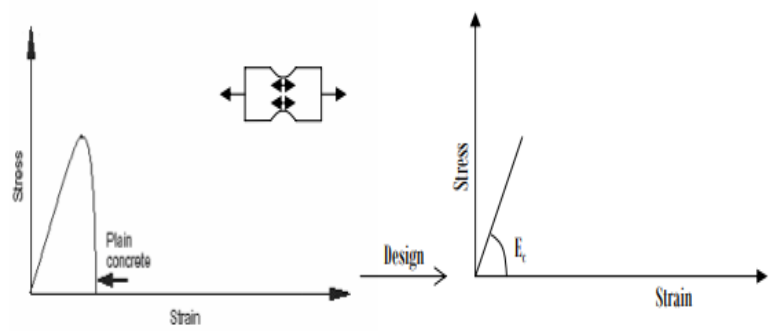

Figure $1 \sigma-\varepsilon$ relationship (Uniaxial tension tests) in plane reinforced concrete

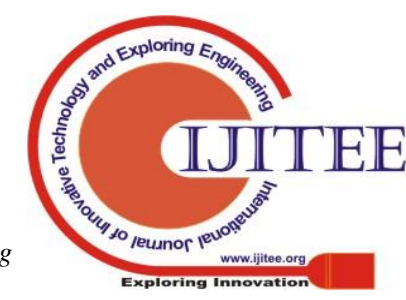


Figure 2 Model used for the design of plane reinforced concrete elements. The post-peak resistance is neglected

The ongoing seismic tremors uncovered the significance of the plan of fortified cement (RC) structures with flexible conduct. Malleability can be portrayed as the capacity of fortified solid cross segments, components and structures to ingest the huge vitality discharged during seismic tremors without losing their quality under huge adequacy and reversible distortions[14]-[18]. This can be established by the potential use of two synthetic fibres like Steel and Polypropylene for improving the ductility as well as toughness of reinforced concrete members

\section{ANALYTICAL STUDY}

A. Finite element analysis of beams Material specification

Table 1 Property of fibers

\begin{tabular}{|c|c|c|}
\hline Properties & Steel & Polypropylene \\
\hline Aspect ratio & 50 & 48 \\
\hline $\begin{array}{c}\text { Young's } \\
\text { modulus(Gpa) }\end{array}$ & 210 & 3.5 \\
\hline $\begin{array}{c}\text { Tensile strength } \\
\text { (Mpa) }\end{array}$ & $1250-1550$ & $300-400$ \\
\hline Type & Hooked - end & Straight Fibrillated \\
\hline
\end{tabular}

The total fibre volume fraction used for casting is $1 \%, 1.5 \%$ and $2 \%$. In this total fibre volume fraction the proportion of steel and polypropylene fibre fraction is as shown in table 2 .

Table 2 Type of mix and its combinations

\begin{tabular}{|c|c|}
\hline Type of mix & $\begin{array}{c}\text { Combinations (Steel: } \\
\text { Polypropylene) }\end{array}$ \\
\hline CC & - \\
\hline \multirow{2}{*}{$\begin{array}{c}\text { 1\% addition of hybrid } \\
\text { fibers in the concrete }\end{array}$} & $(30: 70)$ \\
\cline { 2 - 2 } & $(50: 50)$ \\
\hline \multirow{2}{*}{$\begin{array}{c}\text {..5\% addition of hybrid } \\
\text { fibers in the concrete }\end{array}$} & $(70: 30)$ \\
\cline { 2 - 2 } & $(30: 70)$ \\
\hline \multirow{2}{*}{$\begin{array}{c}\text { 2\% addition of hybrid } \\
\text { fibers in the concrete }\end{array}$} & $(50: 50)$ \\
\cline { 2 - 2 } & $(70: 30)$ \\
\cline { 2 - 2 } & $(30: 70)$ \\
\hline
\end{tabular}

\section{B. Experimental Results}

The inputs required for the beam modeling in ANSYS software are experimentally found out. The compressive strength values are given in Table.

\section{Compressive Strength}

Compressive strength of M35 grade concrete for $1 \%, 1.5 \%$ and $2 \%$ dosage of HFRC is shown in table
Table 3 Compressive Strength of M35 grade concrete for 28 days

\begin{tabular}{|c|c|c|c|}
\hline \multirow{2}{*}{$\begin{array}{c}\text { Percentag } \\
\text { e of fibre }\end{array}$} & \multicolumn{3}{|c|}{ 28 days } \\
\cline { 2 - 4 } & \multicolumn{3}{|c|}{ Dosage of fibre } \\
\cline { 2 - 4 } & $\begin{array}{c}\text { Steel- } \\
\text { polypropylen } \\
\text { e } \\
\end{array}$ & $\begin{array}{c}\text { Steel- } \\
\text { polypropylen } \\
\text { e } \\
\mathbf{( 3 0 - 7 0 )}\end{array}$ & $\begin{array}{c}\text { Steel- } \\
\text { polypropylen } \\
\mathbf{e}\end{array}$ \\
\hline $1 \%$ & 49.5 & 51.58 & $\mathbf{( 7 0 - 3 0 )}$ \\
\hline $1.5 \%$ & 48.76 & 49.82 & 53.33 \\
\hline $2 \%$ & 47.7 & 48.4 & 50.17 \\
\hline
\end{tabular}

\section{Energy Absorption Capacity}

Vitality assimilation limit is characterized as the vitality retained in each cycle equivalent to the stir done in twisting the pillar up to the furthest reaches of avoidance[19]-[22]. It is determined utilizing the region under hysteresis circle for each cycle in load avoidance bend. The vitality retention limit is appeared in table 4 It can been seen that example containing half and half fiber has more vitality ingestion limit than customary cement.

Table 4 Energy absorption capacity

\begin{tabular}{|c|c|c|c|}
\hline \multirow[t]{2}{*}{$\begin{array}{l}\text { Cycl } \\
\text { e no }\end{array}$} & \multicolumn{2}{|c|}{$\begin{array}{l}\text { Energy absorption } \\
\text { capacity }(\mathrm{kN}-\mathrm{mm})\end{array}$} & \multirow{2}{*}{$\begin{array}{l}\text { Cumulative } \\
\text { Energy absorption } \\
\text { capacity (kN-mm) }\end{array}$} \\
\hline & $\begin{array}{l}\text { Conventional } \\
\text { concrete }\end{array}$ & $\begin{array}{l}\text { HFRC } \\
(70-30)\end{array}$ & \\
\hline 1 & 0 & 0 & 0 \\
\hline 2 & 0.5 & 0.75 & 0.75 \\
\hline 3 & 0.7 & 1.2 & 1.95 \\
\hline 4 & 0.85 & 1.4 & 3.35 \\
\hline
\end{tabular}

\section{E. Beam specimens}

Beam of $150 \mathrm{~mm}$ width, $200 \mathrm{~mm}$ height and $1200 \mathrm{~mm}$ span is used for making both conventional concrete and hybrid fibre specimen. In Meshing, discretization of masonry wall into finite element is done. The beam is constrained for two degree of freedom

\section{F. Beam Modelling}

\section{Element type:}

SOLID 65 is utilized for 3-D displaying of strong structures. It is characterized by eight hubs having three degrees of opportunity at every hub: interpretations in the nodal $\mathrm{x}, \mathrm{y}$ and $\mathrm{z}$ bearings[23]-[25]. The component type has the versatility, hyper pliancy, stress hardening, creep, enormous redirection and huge strain abilities. It likewise has blended definition capacities for mimicking distortions of about in compressible elasto-plastic materials and completely incompressible hyper versatile materials. 


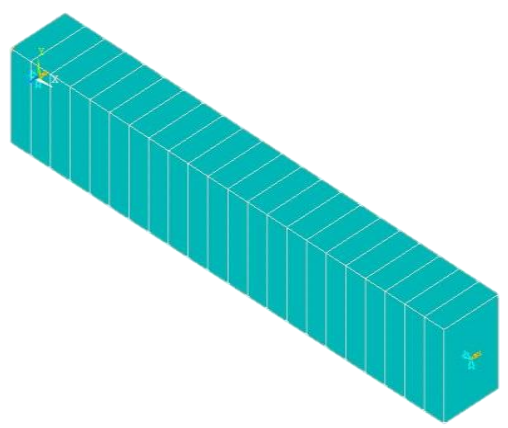

Figure - 3 Modeling of beam in ANSYS

The displacement obtained for the given set of cycle's after analysis as shown in Fig.4 and Fig 5

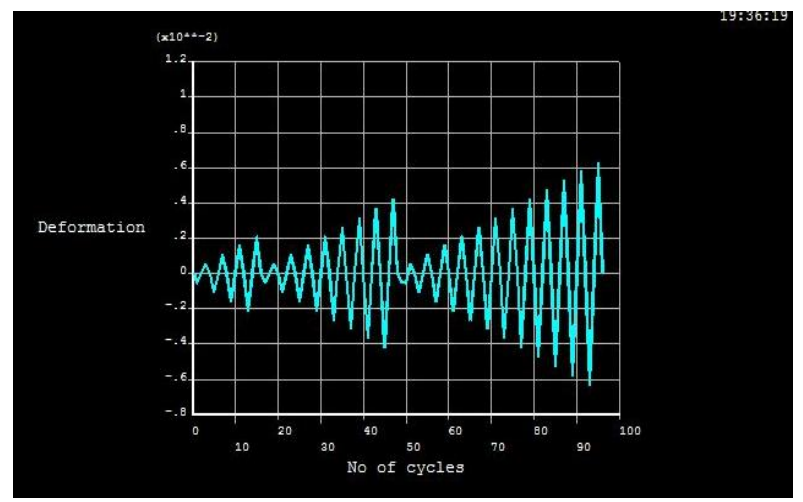

Fig 4 Time history analysis of conventional concrete beam

\section{RESULTS AND DISCUSSIONS}

\section{A. Cyclic Loading Using Ansys Stiffness Ratio}

The stiffness ratio values computed using experimental results and analytical results have difference less than or nearly equal to 1 . The stiffness ratio for forward cycle and reverse cycle of conventional concrete is shown in table 5[26]-[30]

Table 5: Stiffness ratio for conventional concrete beam

\begin{tabular}{|c|c|}
\hline CYCLE NO & STIFFNESS RATIO \\
\hline \multicolumn{2}{|c|}{ FORWARD CYCLE } \\
\hline 1 & 2.55 \\
\hline 2 & 1.99 \\
\hline 3 & 1.55 \\
\hline \multicolumn{2}{|c|}{ REVERSE CYCLE } \\
\hline 1 & 1.65 \\
\hline 2 & 1.44 \\
\hline 3 & 1.20 \\
\hline
\end{tabular}

\begin{tabular}{|c|c|}
\hline CYCLE NO & STIFFNESS RATIO \\
\hline \multicolumn{2}{|c|}{ FORWARD CYCLE } \\
\hline 1 & 1.4 \\
\hline 2 & 1.11 \\
\hline 3 & 0.97 \\
\hline \multicolumn{2}{|c|}{ REVERSE CYCLE } \\
\hline 1 & 0.97 \\
\hline 2 & 0.87 \\
\hline 3 & 1.01 \\
\hline
\end{tabular}

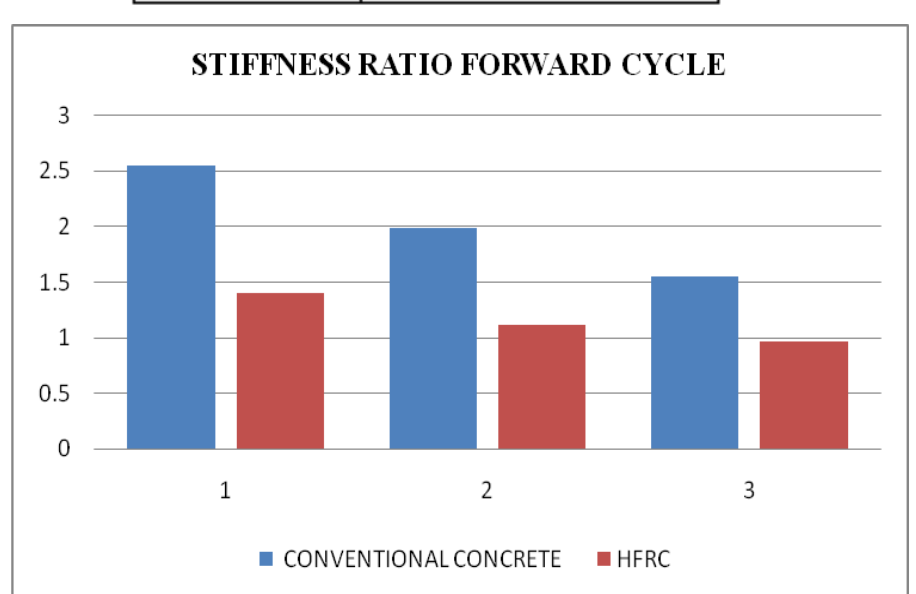

Figure - 5 Stiffness ratio forward cycle for $\mathrm{CC}$ and HFRC

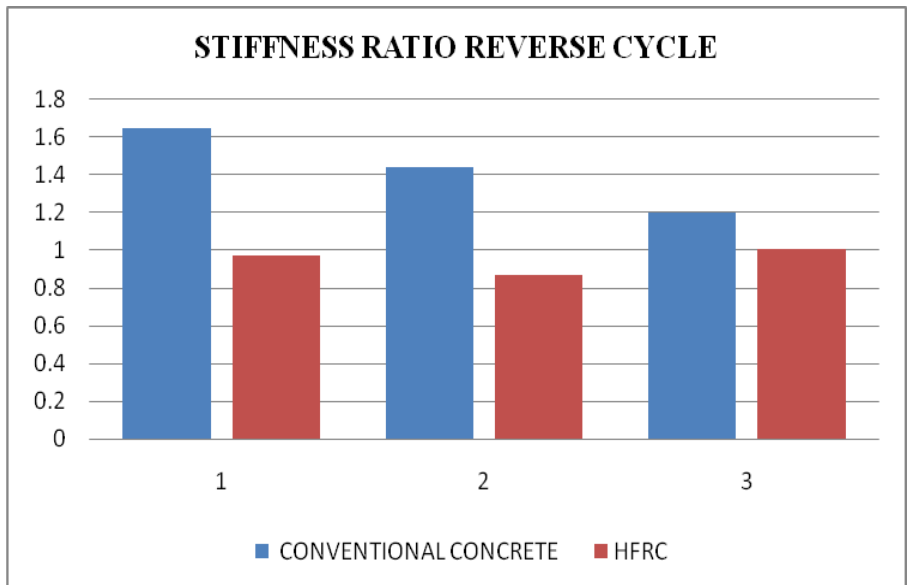

Figure - 6 Stiffness ratio forward cycle for $\mathrm{CC}$ and HFRC

\section{CONCLUSION}

conclusions:

- The addition of $1 \%$ hybrid fibers (70:30, Steel: polypropylene) considerably increases the compressive strength compare to the conventional concrete and as well the other two proposed combinations.

- The prominent compressive strength at $1 \%$ addition of hybrid fibers is $53.33 \mathrm{~N} / \mathrm{mm} 2$ [31]-[34]

- Energy absorption capacity of HFRC beam has been increased in 1.65 times the conventional concrete beam

- The stiffnes ratio of experimental displacement value to analytical displacement value using ANSYS nearly equal to $\approx$ 1.0 


\section{REFERENCES}

1. Iyappan L., Dayakar P., Identification of landslide prone zone for coonoortalukusing spatial technology, International Journal of Applied Engineering Research,V-9,I-22,PP-5724-5732,Y-2014.

2. Kumar J., Sathish Kumar K., Dayakar P.,Effect of microsilica on high strength concrete, International Journal of Applied Engineering Research,V-9,I-22,PP-5427-5432,Y-2014

3. Dayakar P., Vijay Ruthrapathi G., Prakesh J., Management of bio-medical waste, International Journal of Applied Engineering Research,V-9,I-22,PP-5518-5526,Y-2014

4. Swaminathan N., Dayakar P., Resource optimization in construction project, International Journal of Applied Engineering Research,V-9,I-22,PP-5546-5551,Y-2014.

5. Venkat Raman K., Dayakar P., Raju K.V.B.,An experimental study on effect of cone diameters in penetration test on sandy soil, International Journal of Civil Engineering and Technology,V-8,I-8,PP-1581-1588,Y-2017.

6. Saritha B., Chockalingam M.P.,Photodradation of malachite green DYE using TIO2/activated carbon composite,International Journal of Civil Engineering and Technology,V-8,I-8,PP-156-163,Y-2017

7. Shendge R.B., Chockalingam M.P., Saritha B., Ambica A.,Swat modelling for sediment yield: A case study of Ujjani reservoir in Maharashtra, India,International Journal of Civil Engineering and Technology,V-9,I-1,PP-245-252,Y-2018

8. Chockalingam M.P., Balamurgan V.,Modernisation of an existing urban road-sector in Chennai, a case study report,International Journal of Civil Engineering and Technology,V-8,I-8,PP-1457-1467,Y-2017

9. Saritha B., Chockalingam M.P.,Adsorption study on removal of basic dye by modified coconut shell adsorbent, International Journal of Civil Engineering and Technology,V-8,I-8,PP-1370-1374,Y-2017

10. Saritha B., Chockalingam M.P.,Adsorptive removal of heavy metal chromium from aqueous medium using modified natural adsorbent,International Journal of Civil Engineering and Technology,V-8,I-8,PP-1382-1387,Y-2017

11. Chockalingam M.P., Palanivelraja S.,Retrospective analysis of a theoretical model used for forecasting future air quality near the north Chennai thermal power plant,International Journal of Civil Engineering and Technology,V-8,I-8,PP-1457-1467,Y-2017

12. Saritha B., Chockalingam M.P.,Photodegradation of methylene blue dye in aqueous medium by $\mathrm{Fe}-\mathrm{AC} / \mathrm{TiO} 2$ Composite,Nature Environment and Pollution Technology,V-17,I-4,PP-1259-1265,Y-2018

13. Shendge R.B., Chockalingam M.P., Kaviya B., Ambica A.,Estimates of potential evapotranspiration rates by three methods in upper Bhima Basin, In Maharashtra, India,International Journal of Civil Engineering and Technology,V-9,I-2,PP-475-480,Y-2018

14. Shendge R.B., Chockalingam M.P.,The soil and water assessment tool for Ujjani Reservoir,International Journal of Mechanical Engineering and Technology,V-9,I-2,PP-354-359,Y-2018

15. Shendge R.B., Chockalingam M.P.,A review on soil and water assessment tool,International Journal of Mechanical Engineering and Technology,V-9,I-2,PP-347-353,Y-2018

16. Sachithanandam P., Meikandaan T.P., Srividya T.,Steel framed multi storey residential building analysis and design,International Journal of Applied Engineering Research,V-9,I-22,PP-5527-5529,Y-2014

17. Meikandaan T.P., Ramachandra Murthy A.,Study of damaged RC beams repaired by bonding of CFRP laminates,International Journal of Civil Engineering and Technology,V-8,I-2,PP-470-486,Y-2017

18. Meikandaan T.P., Ramachandra Murthy A.,Retrofittng of reinforced concrete beams using GFRP overlays,International Journal of Civil Engineering and Technology,V-8,I-2,PP-423-439,Y-2017

19. Meikandaan T.P., Ramachandra Murthy A.,Flexural behaviour of RC beam wrapped with GFRP sheets,International Journal of Civil Engineering and Technology,V-8,I-2,PP-452-469,Y-2017

20. Meikandaan T.P., Murthy A.R.,Experimental study on strengthening of rc beams using glass Fiber,International Journal of Civil Engineering and Technology,V-9,I-11,PP-959-965,Y-2018

21. Meikandaan T.P., Hemapriya M.,Use of glass FRP sheets as external flexural reinforcement in RCC Beam,International Journal of Civil Engineering and Technology,V-8,I-8,PP-1485-1501,Y-2017

22. Saraswathy R., Saritha B.,Planning of integrated satellite township at Thirumazhisai,International Journal of Applied Engineering Research,V-9,I-22,PP-5558-5560,Y-2014

23. Saritha B., Ilayaraja K., Eqyaabal Z.,Geo textiles and geo synthetics for soil reinforcement,International Journal of Applied Engineering Research,V-9,I-22,PP-5533-5536,Y-2014
24. Ambica A., Saritha B., Changring G., Singh N B., Rajen M., Salman Md.,Analysis of groundwater quality in and around Tambaram taluk, Kancheepuram district,International Journal of Civil Engineering and Technology,V-8,I-8,PP-1362-1369,Y-2017

25. Arunya A., Sarayu K., Ramachandra Murthy A., Iyer N.R.,Enhancement of durability properties of bioconcrete incorporated with nano silica,International Journal of Civil Engineering and Technology,V-8,I-8,PP-1388-1394,Y-2017

26. Ilayaraja K., Krishnamurthy R.R., Jayaprakash M., Velmurugan P.M., Muthuraj S.,Characterization of the 26 December 2004 tsunami deposits in Andaman Islands (Bay of Bengal, India),Environmental Earth Sciences,V-66,I-8,PP-2459-2476,Y-2012

27. Ilayaraja K.,Morphometric parameters of micro watershed in Paravanar sub-basin, Cuddalore District,International Journal of Civil Engineering and Technology,V-8,I-8,PP-1444-1449,Y-2017

28. Ilayaraja K., Singh R.K., Rana N., Chauhan R., Sutradhar N.,Site suitability assessment for residential areas in south Chennai region using remote sensing and GIS techniques,International Journal of Civil Engineering and Technology,V-8,I-8,PP-1468-1475,Y-2017

29. Ilayaraja K., Reza W., Kumar V., Paul S., Chowdhary R.,Estimation of land surface temperature of Chennai metropolitan area using Landsat images,International Journal of Civil Engineering and Technology,V-8,I-8,PP-1450-1456,Y-2017

30. Chitra R.,Experimental study on beam using steel fiber and latex,International Journal of Civil Engineering and Technology,V-8,I-8,PP-1395-1403,Y-2017

31. Chitra R.,Analysis of traffic and management at Kovilambakkam intersection,International Journal of Civil Engineering and Technology,V-8,I-8,PP-1433-1443,Y-2017

32. Aswathy M.,Experimental study on light weight foamed concrete,International Journal of Civil Engineering and Technology,V-8,I-8,PP-1404-1412,Y-2017

33. Aswathy M.,Wastewater treatment using constructed wetland with water lettuce (Eichornia Crasipies),International Journal of Civil Engineering and Technology,V-8,I-8,PP-1413-1421,Y-2017

34. Kiruthiga K., Anandh K.S., Gunasekaran K, Assessment of influencing factors on improving effectiveness and productivity of construction engineers, 2015, International Journal of Applied Engineering Research, V - 10,I -17,p -13849-13854.

\section{AUTHORS PROFILE}

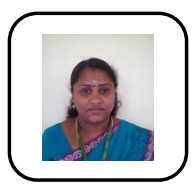

M.Hemapriya Assistant Professor, Department of Civil Engineering, Bharath Institute of Higher Education and Research, Chennai, India.

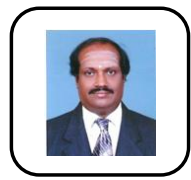

T.P.Meikandaan Associate Professor, Department of Civil Engineering, Bharath Institute of Higher Education and Research, Chennai, India.

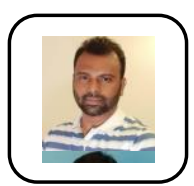

A. Arokia Prakash M Tech Student, Department of Civil Engineering, Bharath Institute of Higher Education and Research, Chennai, India. 